\title{
ПАУПЕРИЗМ В СТАНОВЛЕНИИ СОЦИАЛЬНОЙ ПОЛИТИКИ ВЕЛИКОБРИТАНИИ
}

В статье рассматривается проблема пауперизма, как фактор становления социальной политики Великобритании в первой половине XIX века. Проблема нищеты, являясь частью социальной политики любого государства, имела свои исторические особенности решения этого вопроса и в Британии, зависящие от роста и миграции населения, традиций государственного и местного управления. Роль и динамика пауперизма в становлении социальной политики Британии является дискуссионной проблемой в отечественной и зарубежной историографии. В первой половине XIX века пауперизм последовательно анализировался парламентом и прессой, философами и юристами, а также статистиками и врачами. В эпоху урбанизации, после введения системы переписей населения призрение пауперов стало восприниматься в обществе, как проблема социальных расходов и налогообложения. Автор приходит к выводу, что после унии 1800 года с Ирландией, в эпоху урбанизации шло становление социальной политики на базе анализа статистических данных, изменения законов о бедных, введения системы здравоохранения городов Соединённого Королевства Великобритании и Ирландии. Согласно новому «Закону о поправках и более лучшем ведении законов о бедных в Англии и Уэльсе, 1834» работоспособное население должно было само- стоятельно обеспечивать себя вне пределов прихода. Новый закон стал отправной точкой утилитаристского распределения налогов и государственных расходов, становления социальной политики, координируемой не приходами, а новыми государственными органами по закону о бедных. В дальнейшем соответствующие социальные реформы охватили Ирландию и Шотландию. Предлагалось создать государственную систему социальной помощи для малоимущих, женщин, детей, больных, вдов и сирот всего Соединённого Королевства. Деятельность Комиссии по закону о бедных контролировалась парламентом посредством отчётов, широко обсуждалась в прессе. Реформа пауперизма была направлена на кардинальное решение проблем налогообложения, здравоохранения, совершенствования системы выплат социальных пособий и обеспечения благосостояния всего британского общества. В эпоху урбанизации Соединённое Королевство Великобритании и Ирландии переходило от приходской системы поддержки пауперов к совершенствованию налогообложения, социальных расходов и здравоохранению городов.

Ключевые слова: социальная политика, пауперизм урбанизация, Эдвин Чедвик, Великобритания, Шотландия, Ирландия.

\section{PAUPERISM IN THE RISE OF SOCIAL POLICY OF GREAT BRITAIN}

The paper examines the problems of pauperism as the factor of the rise of social policy of Great Britain in the first half of the XIX century. The problem of misery, as a part of social policy of every state of the world, had its historical peculiarities of solution in Great Britain that depended on the growth and migration of population, traditions of the state and local government. The role and dynamics of pauperism in the rise of social policy of Great Britain is a topical problem in domestic and foreign historiography. In the first half of the XIX century, the problems of pauperism were consistently analyzed by the parliament and the press, philosophies and lawyers, statistics and doctors. During the period of urbanization after the introduction of the system of population census, the pauperism began to seen as a coercive burden of taxation. The author concludes that after the Union with Ireland in 1800 , during the epoch of urbanization, the rise of social policy took place on the base of statistics analysis, changes of the poor laws, the introduction of the healthcare system in the towns of the United Kingdom of Great Britain and Ireland. According to the new Poor law of 1834 in England and Wales, the capable population must provide themselves outside the parish. The new law became the starting point of utilitarian distribution of taxes and state expenses, the rise of the social policy, coordinated not by the parishes, but by the new state authorities in line with the new poor law. Then social reforms spread in Scotland and Ireland. It was supposed to create the state system of social assistance for the poor, woman, children, the sick, widows and orphans all over the kingdom. The activity of the Commission for the Poor laws was controlled by the parliament through reports; it was discussed in the press. The pauperism reform was aimed at cardinal decision of the problem of taxation, public health, modernization of the system of social allowance, and the provision of the welfare to the whole society. During the urbanization period, the United Kingdom of Great Britain and Ireland fell from the parochial system of the poor relief to the modernization of the social expenses and healthcare in the towns.

Key words: social policy, pauperism, urbanization, Edwin Chadwick, Great Britain, Scotland, Ireland. 
Проблема нищеты является частью социальной политики любого государства мира, имея свои исторические особенности решения этого вопроса, зависящие от количества мигрантов, малоимущего и имущего населения, особенностей национального менталитета, сложившихся традиций государственного, религиозного и местного управления. Роль и динамика пауперизма в становлении социальной политики Соединённого Королевства Великобритании и Ирландии является дискуссионной проблемой в отечественной и зарубежной историографии. Отношение британского общества к пауперам и проблеме нищеты, способы решения соответствующих социально-экономических проблем стали объектом ряда дискуссий и в первой половине XIX века.

Целью данного исследования является необходимость определения особенностей и роли пауперизма в становлении социальной политики Соединённого Королевства Великобритании и Ирландии в первой половине XIX столетия.

Призрение пауперов являлось частью государственной политики Великобритании, начиная c XVII века. Для этого ещё в период царствования королевы Елизаветы на основе закона 1601 года был введён специальный налог в пользу бедных ставший до XIX века главным видом налогообложения населения в Англии и Уэльсе. По мнению русского земского общественного деятеля XIX века, князя А. Васильчикова, с древних времён англичане вели «Гласную статистику общественного призрения пауперов, между тем как в других государствах Европы нищенство утаивается как постыдные язвы, которые необходимо было скрыть от глаз цивилизованной публики» [3, с. 87]

После унии 1800 года с Ирландией, введения системы переписей населения, в эпоху промышленного переворота и урбанизации, проблема призрения пауперов приобрела новые черты, последствия, и значение которых не достаточно исследованы, как фактор становления социальной политики Соединённого Королевства Великобритании и Ирландии. В начале XIX века в период роста количества городов и населения пауперизм стал неоднозначно рассматриваться обществом и налогоплательщиками. «Буржуазию не устраивала старая система, при которой низовая административная единица - приход - обязана была за счёт местных налогов содержать постоянно проживающих в данном приходе бедняков, если они лишались источников существования. Массы разоряемых в ходе промышленного переворота крестьян и ремесленников неохотно оставляли свой приход, где им не грозила голодная смерть, а это сдерживало приток рабочей силы в новые промышленные центры» [5, с. 159]. Налогоплательщики Соединённого Королевства стремились контролировать государственные и местные социальные расходы для их снижения, а также для развития нового индустриального общества. Устаревшая политика поддержки пауперов, усугубляя социально-экономические проблемы королевства, на протяжении ряда лет стала постоян- ным объектом дебатов британского парламента $[17,18,19,20,21,22]$.

После унии с Ирландией и введения в 1800 году системы переписей населения проблема пауперизма, налогообложения и роста социальных расходов стала ещё более острой. Следствием промышленного переворота и урбанизации стал резкий рост населения промышленных городов страны, сопровождающийся миграцией населения в Лондон, развивающиеся порты и индустриальные центры. По мнению Э. Брандажа, социальные расходы и пособия пауперам в начале XIX века увеличились значительно [15, р. 40]. По мнению Н. А. Ерофеева в эпоху промышленного переворота, в начале XIX века «Английский пауперизм всё более отождествлялся с положением рабочего класса» [4, с. 131].

Многовековая система поддержки бедных, сохранив определённую преемственность, сыграла одну из определяющих ролей в становлении социальной политики Соединённого Королевства Великобритании и Ирландии. Проблемы пауперизма последовательно анализировались государственными деятелями, парламентом и прессой, философами, юристами и врачами. Однако оценки новой реформы по закону о бедных и соответствующей государственной политики королевства вызывают неоднозначные мнения в отечественной и зарубежной историографии. А. Мортон дал субъективно-негативную оценку деятельности и руководителей Комиссии по закону о бедных, придерживаясь марксистской методологии и отмечая, чтобы «избежать общественного контроля» над проведением закона 1834 года о бедных «назначили трёх уполномоченных, фактически не несущих ответственности ни перед кем... три короля сомерсетского дома, которые на протяжении десятилетия вместе с их секретарём Э. Чедвиком были самыми ненавистными людьми в Англии» [6, с. 332]. По мнению Л. Е. Кертмана «закон 1834 года формально сохранил систему общественной помощи бедным, но настолько извратил и ресормировал её, что она превратилась в жестокое издевательство над миллионами тружеников. Отныне выдача пособия полностью прекращалась, а пауперы, обращавшиеся за помощью, помещались в работные дома, где их содержали на грани голода, заставляя выполнять помногу часов бессмысленную работу... прислуживать деспотам-надзирателям... Сама идея нового закона требовала, чтобы жизнь в работном доме была невыносимой, чтобы бедняк предпочёл любые условия труда получению общественной «помощи» [5, с. 196].

Такая негативная критика нового закона о бедных 1834 года, а также деятельности Эдвина Чедвика и нового Комиссии по закону о бедных субъективна и не справедлива. Реформирование системы пауперизма имело, как негативные, так и позитивные черты. Промышленный переворот, рост и миграция населения, проблемы здравоохранения городов требовали изменения устаревших практик доиндустриального государ- 
ственного управления. Ю. Е. Барлова, сравнивая различные законы о бедных, указывала, что У. Питт-младший «может считаться последним министром, защищавшим «старую систему» и открытое призрение», после второго срока премьерства, и ухода в отставку которого, в 1806 году, «обостряется критика «старой системы» в общественно-политических кругах» [2, с. 27-30]. И. Редлих назвал Эдвина Чедвика (юриста и основателя системы общественного здравоохранения Великобритании) «духовным творцом реформы по закону о бедных 1834 года» [8, с. 160]. Однако Н. Эдсалл считал “духовными отцами» нового закона о бедных 1834 года - философа Джереми Бентама и профрессора университета Оксфорда, члена Лондонского Королевского научного общества Томаса Мальтуса, рассматривая их, как «учителей Н. Сениора и Э. Чедвика» [16, p. 2]. К. Поланьи, сравнивая социальные законы, отмечал, что «социальное сознание формировалось по модели, заданной Спинхемлендом» [7].

Согласно новому «Закону о поправках и более лучшем ведении законов о бедных в Англии и Уэльсе, 1834» в эпоху промышленного переворота и урбанизации всё работоспособное население Соединённого Королевства Великобритании и Ирландии должно было трудиться, обеспечивая себя самостоятельно за пределами британских приходов, но на новых промышленных предприятиях [11]. После утверждения нового закона в состав новой государственной Комиссии по закону о бедных 1834 года вошли Т. Льюис (представлявший тори и занимавшийся разработкой предыдущих законов о бедных), Дж. Николс (сотрудник банка Англии, работавший в Бирмингеме), а также бентамисты - Ш. Лефевр и Э. Чедвик.

В дальнейшем централизованные Комитет и Совет по закону о бедных стали прообразом централизованного Генерального совета здравоохранения, созданного согласно принятого «Закона об обеспечении общественного здравоохранения, 1848 ». Э. Чедвик, будучи секретарём этих новых структур государственного управления, стал разработчиком важнейших социальных законов и принципов социальной политики Соединённого Королевства Великобритании и Ирландии. В 1830-1840-е гг. создаётся централизованная система, координирующая становление социальной политики Великобритании, затрагивающей интересы всех слоёв населения королевства. Комитет по соблюдению нового закона о бедных 1834 года проводил соответствующие социальные исследования и реформы. В его компетенцию вошёл широкий спектр социальных проблем урбанизации: проблемы нищеты, преступности, эпидемий, миграции, здравоохранения, социальной поддержки женщин и детей. Комитет уполномочивался «реорганизовать около 15000 английских и уэльских приходов в «Союзы о бедных» (Poor Law Unions), каждый из которых в обязательном порядке организовывал свой работный дом. Так был воплощён первый из принципов реформы - централизация системы социального призрения" [2, с. 30]. Мигранты Соединённого
Королевства могли по новому закону о бедных 1834 года получать социальную помощь в городах. Однако на новых быстрорастущих заводах и фабриках промышленных городов требовались рабочие, поэтому бывшие пауперы предпочитали работать, нежели находиться в работных домах. Эпоха индустриализации и урбанизации требовала выработки новых социально-экономических условий и законов, соответствующих развитию нового вида общественного развития Соединённого Королевства.

Необходимо также подчеркнуть, что деятельность нового Комитета по соблюдению нового закона о бедных 1834 года не была, как указывал А. Мортон бесконтрольной. Социальная деятельность этой новой государственной организации, а также новые работные дома и соблюдение нового закона о бедных контролировались британским парламентом [21, 22], посредством социальных отчётов $[26,28]$

Пересмотр устаревших законов о бедных вызвал ряд длительных дискуссий в королевстве. Депутат парламента Р. Слэни отметил, что целью законов о бедных был поиск работы для работоспособных. Депутат Хортон указал, что «налог в пользу бедных обременял развитие промышленности». В конце 1830-х годов лорд Бругэм и лорд Хатертон, виконт Мельбурн, граф Ф. Уильям, представляя петиции из Пейсли, Норсхемптона, выступили «за отмену приходских налогов на бедных». Но лорд Шефтстбери, петиции из Элмли и Нетервента были против их отмены. Лорд Стенхоуп, представители различных приходов Лондона предлагали поддержать лорда Бругэма и введение нового закона о бедных 1834 года [20].

Врач и философ Дж. Таунсенд ещё на рубеже XVIII-XIX веков выступил против приходской помощи трудоспособным пауперам Великобритании. Однако он отмечал необходимость сохранения определённой социальной поддержки, подчёркивая, что «соответствующие налоги собираются добровольно и в Голландии». Он полагал, что собираемые еженедельно средства в качестве помощи пауперам Великобритании, "растрачиваются попусту». Дж. Таунсенд считал, что «болезни - это одна из главных причин пауперизма», предлагая вести лечение пауперов в больницах Англии по примеру Франции (больницы Сальпетриер около Парижа), одновременно вынуждая пауперов «заняться поисками работы за заработанную плату». «Помощь многодетным семьям", по существующим законам о бедных, по его мнению, «искусственно стимулировала рождаемость пауперов» [35]

Профессор истории и политэкономии университета Оксфорда Т. Мальтус, член Лондонского Королевского научного общества, Парижской Академии наук, Королевской Академии Берлина, священнослужитель, сторонник вигов разделял идеи Дж. Таунсенда о росте населения и соответствующих пособий. Т. Мальтус был сторонником принципа «laissez-faire», «улучшения положения и увеличения счастья низших классов общества», порицая общественную помощь и ранние 
браки, полагая, что население увеличивается в геометрической прогрессии каждые двадцать пять лет, что является коренной причиной социальных бедствий и роста нищеты. Для сравнения проблем народонаселения и опыта филантропии он посетил ряд зарубежных стран - Данию, Ирландию, Норвегию, Швейцарию, Швецию, Германию и Россию. Профрессор предлагал упразднить устаревшую систему поддержки пауперов по законам о бедных ещё в конце XVIII века [24].

Анализируя и развивая идеи решения проблемы пауперизма, социальный мыслитель Джереми Бентам, предлагал сократить налог на бедных заставив трудоспособных пауперов работать, перестать быть иждивенцами у налогоплательщиков в противовес их пребывания в работных домах. Его идеи предполагали укрепление частной собственности и морали, а также инспекцию социальных условий жизни и работы пауперов, работных домов, больниц, предприятий, утилитаризм государственных и местных расходов [14]. Проблема нищеты и реформа пауперизма в первой половине XIX века последовательно анализировалась, совершенствуясь в парламенте Великобритании [32], отчёте Министру внутренних дел Комиссии по закону о бедных [30], на страницах периодической печати [25, 32]. В эпоху урбанизации и окончания наполеоновских войн на страницах прессы появились социальные отчёты и статьи, посвящённые улучшению положения пауперов [34]. «Благодаря средствам массовой информации рост смертности и эпидемий, проблем загрязнения городов, отсутствия санитарно-технических сооружений, фальсификация продуктов питания и лекарств, а также проблемы гигиены, трущоб, пауперизма приобретали социальное значение» $[9$, с. 112].

В 1817 году парламент назначил «Избранный комитет палаты общин по законам о бедных» под руководством Ст. Бурна. В итоге работы комитета парламент Великобритании утвердил закон, предусматривающий обязательные расходы казначейства на обеспечение занятости бедных на общественных работах, в том числе и Ирландии [13].

Пример Шотландии в решении социальных проблем пауперизма неоднократно обсуждался в парламенте в 1807-1818 годах. Депутаты отметили положительный опыт этой части Соединённого Королевства в вопросе обучения детей пауперов за счёт приходов, подчеркнув, что использование налога на бедных для обучения детей пауперов не является «тяжким бременем», поскольку используется для поддержания морали подрастающего поколения [17]. В ходе парламентских дебатов 1817 года указывалось, что в Шотландии пауперы Глазго должны получать пособия лишь по месту своего рождения или после трёх лет проживания в определённой местности [19] Отчёт Избранного комитета по закону о бедных 1819 года также отмечал пример Шотландии в решении проблем нищеты для Англии и Уэльса [33]

Ведущие статистики и экономисты Великобритании подчёркивали тесную взаимосвязь между экономической и социальной организацией государства. В 1828 году Дж. Маккулоч опубликовал специальную статью, посвящённую проблеме пауперизма. Британский статистик отмечал, что до XIX века, существующие английские законы о бедных не стимулировали столь резкий рост населения городов, что может быть скопировано и в Ирландии [25]. Профессор политэкономии университета Оксфорда Н. У. Сениор был одним из ведущих экономистов своего времени. Благодаря своим знаниям и авторитету он стал советником партии вигов, приобрёл влияние в интеллектуальной среде страны, содействуя становлению социальной политики Великобритании. Убеждённость в том, что новый закон о бедных кардинально решит проблему налогов, пособий, нищеты и благосостояния всего британского общества определила становление социальной политики королевства. В 1832 году парламентом была назначена специальная Комиссия для расследования масштабов и последствий пауперизма. Профессор Н. Сениор, возглавив эту комиссию, предложил парламенту утвердить поправки о более лучшем ведении законов о бедных в Англии и Уэльсе. Зная Э. Чедвика, как последователя идей Дж. Бентама и квалифицированного юриста, он пригласил его для совместной работы в новой комиссии. «Отчёт членов Комиссии для обследования применения на практике законов о бедных», составленный Н. Сениором и Э. Чедвиком, отразил государственные масштабы проблемы пауперизма, а также необходимость введения нового закона о бедных [26]. В дальнейшем профессор Н. Сениор занимался реформой законов о бедных и в Ирландии [29].

Оценивая закон о бедных 1834 года, Ю. Е. Барлова указывала, что «реформа не была подобна перевороту или революции в социальном призрении». Сопоставление законов о бедных показывает, что новый акт «не был коренной ломкой старого... элементы новой системы проявлялись в законотворчестве уже с первой половины XVIII века» $[2$, с. $27-30]$.

Однако необходимо отметить, что «Закон о поправках и более лучшем ведении законов о бедных в Англии и Уэльсе, 1834», предшествующие парламентские исследования стали следствием урбанизации, которая началась вместе с промышленным переворотом ещё в XVIII веке Урбанизация сопровождалась ростом количества малоимущих и трущоб, миграцией пауперов в промышленные города.

Идеи реформы 1834 года стали основой становления социальной политики и здравоохранения городов Британии. Э. Брандаж отмечал, что в Великобритании после введения закона 1834 года в общественный оборот вошло понятие "старого» и «нового» законов о бедных, поскольку старая приходская система помощи бедным устарела [15, р. 7]. В «Отчёте членов Комиссии для обследования применения на практике законов о бедных" отмечалось, что главная проблема роста социальных расходов - это деморализующий эффект обеспечения пособием трудоспособ- 
ных бедняков. Подчёркивалось, что реорганизация устаревшей системы приходской помощи для пауперов сократит расходы на их обеспечение, [26, p. 63-67]. Но предлагалось создать новую систему поддержки вдов, малоимущих женщин и детей, больных и сирот. В британском парламенте акт о бедных 1834 г. был охарактеризован, как «новый закон о бедных» [22].

На рубеже XX-XXI веков исследователи противоречиво оценивали идеи решения проблем пауперизма. По мнению Т. Ю. Сидориной, работные дома рассматривались, как решение проблем «социального надзора», «призрения за пауперами городов», «социально опасными слоями», но с другой стороны - это было «трудоустройство и выполнение общественно-полезных функций», а «ужасы пребывания в работных домах стимулировали нищих к поиску работы... Работные дома в Англии представляли попытку в рамках социальной политики решить проблемы бедности, бродяжничества и трудоустройства» [10, с. 212].

И. Левит указывал, что «Закон о поправках и более лучшем ведении законов о бедных в Англии и Уэльсе, 1834» стал новой эрой «утилитаристского управления», синтезом «мальтузианского фотализма и идеологии «laissez-faire», направленной на контроль «распределения благосостояния», ставшего отчётливо выраженным в годы наполеоновских войн, когда более $20 \%$ населения юга Англии получали приходскую помощь [23, p. 160]

Депутаты британского парламента обсуждали положительные стороны общественной помощи, существующей при работных домах Англии, а также для пауперов Ирландии, не получающих подобную социальную помощь [18]. 21 июля 1834 года лорд Бругэм, выступая в палате лордов в ходе второго чтения законопроекта о пауперах, поддерживая новый закон, подчеркнул необходимость перераспределения местных церковных доходов на бедных [31, р. 310].

В итоге длительных дискуссий рекомендации членов Комиссии для обследования применения на практике законов о бедных легли в основу нового «Закона о поправках и более лучшем ведении законов о бедных в Англии и Уэльсе, 1834» [11]. В 1830-1840-х годах новые социальные реформы охватили Шотландию и Ирландию. 31 июля 1838 года новый закон о бедных был принят в Ирландии, а в 1845 году - и в Шотландии [12]. Новые законы о бедных отменяли приходское пособие по бедности, создавая работные дома, как новый вид социальной помощи Соединённого Королевства Великобритании и Ирландии. «Национальные и местные комитеты, начиная с 1845 года, осуществляли надзор за законодательством для бедных и создали настолько успешную модель управления, что она была не раз копируема в другие отрасли управления. Эти институты были промежуточным звеном между центральным правительством и народом на территории Шотландии. В органы местного самоуправления входили представители среднего класса, профес- сиональные юристы, предприниматели, врачи» $[1$, c. $152-153]$

В конце 1830-х годов члены государственного Комитета по закону о бедных обратили внимание британского парламента на необходимость изменения системы налогообложения в пользу пауперов, перераспределив получаемые средства, на предупреждение эпидемий, снижение заболеваемости и смертности. Обосновывая эту новую идею, Эдвин Чедвик информировал Министра внутренних дел Соединённого Королевства Великобритании и Ирландии лорда Дж. Расселла, о необходимости санитарного обследования королевства. Отмечалось, что новый «Закон о поправках и более лучшем ведении законов о бедных в Англии и Уэльсе, 1834» «нуждается в дальнейших поправках и добавлениях", не обеспечивая потребности этой категории населения, а «приостановить рост нищеты можно» лишь путём политики предупреждения медикосоциальных проблем. Подчёркивая, что это будет «дешевле выплат пособий» вдовам и сиротам, рефрорматор предлагал эту новую работу сделать компетенцией государственной Комиссии по закону о бедных, а не местным приходам. Отчёты врачей Н. Арнотта, Дж. Кейя, С. Смита констатировали значительный рост трущоб в столице Великобритании, указывая на «экономическую пользу для государства систематических социальных мер» [32]. Утилитаризм государственных расходов стал ведущей идеей новых социальных реформ Соединённого Королевства Великобритании и Ирландии.

Оба отчёта были представлены в парламент Министру внутренних дел Великобритании лорду Дж. Расселлу, и широко обсуждались в прессе. Первые утилитаристские отчёты о положении пауперов и лондонских трущоб, представленные врачами и Комиссией по закону о бедных в парламент, положили начало становления социальной политики. Отчёты предлагали разработку ряда новых законов для совершенствования системы коммунальных услуг в рабочих и национальных кварталах мигрантов (водоснабжения, дренажа, уборки улиц и т.п.). Проведение медикосоциальных реформ предлагалось, как альтернатива для снижения уровня смертности и налогов на бедных.

В итоге в 1839 году правительство Великобритании поручило Комиссии по закону о бедных установить масштабы социальных проблем в Англии и Уэльсе, а затем и санитарных условий всего Соединённого Королевства Великобритании и Ирландии. Обследования 1839-1842 годов доказали антисанитарное положение городов Соединённого Королевства. В 1842 году итоговый «Отчёт членов Комиссии по закону о бедных Министру внутренних дел или Расследование о санитарном положении рабочего населения Великобритании» был представлен в парламент по приказу королевы Виктории [27]. Тщательный анализ развития промышленных городов в контексте пауперизма подтверждал выводы членов Комиссии по закону о бедных (докторов С. Смита, Н. Арнотта, Дж. Кейя и юриста Э. Чедвика) 
o том, что антисанитарные условия наносили вред индустриальному обществу. Отмечалось что существующие британские законы устарели, не решая медикосоциальных проблем. В отчёте был представлен ряд рекомендаций: пересмотр сложившейся системы социальных расходов на местном и государственном уровне, введение централизации управления городов, использование статистики, обязательное введение должности санитарного врача. Эти меры предлагались в противовес нецелесообразным выплатам приходских пособий малоимущим. В эпоху урбанизации пауперизм и здравоохранение городов стали центральными проблемами социального развития Соединённого Королевства Великобритании и Ирландии.

Середина XIX века стала периодом становления социальной политики Соединённого Королевства Великобритании и Ирландии. При открытии очередной сессии британского парламента в 1844 году королева Виктория провозгласила что «Public Policy» - важнейший вопрос для благосостояния всех классов" Соединённого Королевства Великобритании и Ирландии. Подчёркивалось, что меры по улучшению «социальных условий Ирландии будут продолжены», а вмешательство правительства необходимо «для пользы общества» [21]. Отмечалось, что “отныне началась великая и всесторонняя реформа внутреннего управления». «Руководящей идеей было "общественное здоровье" [8, с. 187]. В период Крымской войны 1853-1856 годов «определились новые направления социальных реформ, пересмотр приходской политики по закону о бедных и здравоохранения городов» [30, с. 27]. Урбанизация, пауперизм и рост медикосоциальных проблем требовали систематических государственных мер и расходов Соединённого Королевства

Таким образом, в эпоху урбанизации после унии 1800 года с Ирландией шло становление социальной политики Соединённого Королевства Великобритании и Ирландии. Реформа законов - бедных привела к ломке приходского сознания, став отправной точкой утилитаристского распределения налогов и государственных расходов, а также становления целенаправленной социальной политики, координируемой новыми государственными органами власти, а не приходами. Приобретая характер национальных дебатов, проблемы пауперизма периодически обсуждались парламентариями, вигами и тори философами, юристами, врачами, священнос- лужителями, членами Лондонского Королевского общества. В XIX веке следствием промышленного переворота, эпидемий, роста городов и населения, миграции явилось изменение отношения общества к роли приходов, проблеме нищеты и призрению бедных. Устаревшая система использования налога на бедных стала обременять поступательное развитие промышленных городов. Пауперы стали восприниматься обществом, как тунеядцы, но женщины, вдовы, дети, больные, а также неработоспособные члены британского общества могли в работных домах получить фиксированную социальную и медицинскую помощь. Призрение пауперов стало общегосударственной проблемой промышленных городов, центральным объектом государственного контроля, научных и социальных исследований Соединённого Королевства. Идеи социальных реформ рассматривались в контексте роста городов и населения, переписей населения, утилитаризма, политэкономии, здравоохранения городов, определив становление социальной политики Великобритании. Законы о бедных формировалась под влиянием социальных идей (Дж. Таунсенда Дж. Бентама, Т. Мальтуса, Ст. Бурна, Н. Сениора, лорда Бругэма), Комиссии по закону о бедных, примера Шотландии, после унии 1800 года с Ирландией. Развивая социальные идеи своих предшественников, члены Комитета по закону о бедных указали на необходимость полного изменения внутренней политики Соединённого Королевства, заставив британский парламент начать её пересмотр. Выводы Комиссии по закону о бедных, дополняли друг друга, требуя санитарных мер, кардинального решения проблемы налогов, пособий, нищеты и обеспечения благосостояния населения, а также целенаправленного государственного вмешательства в решение социальных проблем. Медикосоциальные отчёты отражали демографические последствия урбанизации, изменение взглядов государства на необходимость общественного здравоохранения и реформу пауперизма, обусловленную социальными причинами. Великобритания переходила от приходской системы поддержки пауперов к пересмотру налогов, развитию промышленных городов, обеспечению занятости мигрантов, увеличению социальных расходов и пособий, здравоохранению городов. В эпоху урбанизации синтез всех этих идей и реформ положил начало становлению социальной политики Соединённого Королевства Великобритании и Ирландии.

\section{Источники и литература}

1. Апрыщенко В. Ю. Уния и модернизация: становление шотландской идентичности в XVIII - первой половине XIX вв. Ростов н/Д: Изд-во ЮФУ, 2008. 288 с.

2. Барлова Ю. Е. Английское законодательство о бедных в XVIII - первой половине XIX в. // Ярославский педагогический вестник. 2010. Т.1. № 3. С. 27-30.

3. Васильчиков А. И. О самоуправлении. Сравнительный обзор русских и иностранных земских и общественных учреждений. СПб.: тип. Э. Пратца, 1872. Т. 1. 352 с.

4. Ерофеев Н. А. Народная эмиграция и классовая борьба в Англии в 1825-1850 гг. М.: АН СССР, 1962. 536 с.

5. Кертман Л. Е. География, история и культура Англии. 2-е изд. М.: Высшая школа, 1979. 384 с.

6. Мортон А. Л. История Англии. М.: ИЛ,1950. 462 с. 
7. Поланьи К. Великая трансформация: политические и экономические истоки нашего времени. СПб.: Алетейя 2002. $320 \mathrm{c}$

8. Редлих И. Английское местное управление. СПб.: Тип. Альтшулера, 1907. 443 с.

9. Сидоренко Ю. А., Склярова Е. К., Бутова Е. Н. Формирование социогигиенических идей в эпоху урбанизации Великобритании / Ю. А Сидоренко, Е. К., Склярова, Е. Н. Бутова // Гуманитарные и социально-экономические науки. 2018. № 2 (99). С. 109-114.

10. Сидорина Т. Ю. Два века социальной политики. М.: РГГУ, 2005. 442 с.

11. An Act for the Amendment and Better Administration of the Laws Relating to the Poor in England and Wales, $1834 / / 4$ \& 5 Will. IV. c. 76

12. An Act for the More Effectual Relief of the Destitute Poor in Ireland, $1838 / / 1 \& 2$ Vict. c.56; An Act for the Amendment and Better Administration of the Laws Relating to the Relief of the Poor in Scotland, $1845 / /$ Vict. 8 \& 9 c. 83.

13. An Act to amend an Act made in the Present Session of Parliament, for authorizing the Issue of Exchequer Bills, and the Advance of Money for carrying on Public Works and Fisheries, and Employment of the Poor, 1817 // 57 Geo. III c. 34.

14. Bentham J. Writings on the Poor Laws. Vol. I. / Ed. by M. Quinn. Oxford: OUP, 2001. $359 \mathrm{p}$.

15. Brundage A. The English Poor Laws, 1700-1930. N.Y.: Palgrave, 2002. 185 p.

16. Edsall N. The Anti-Poor Law Movement 1831-1844. Manchester: Manchester University Press, 1971. 285 p.

17. Hansard's Parliamentary Debates. 1-st Series. 1807. Vol. IX. c. 541.

18. Hansard's Parliamentary Debates. 1-st Series. 1809. Vol. XIV c. 645.

19. Hansard's Parliamentary Debates. 1-st Series. 1817. Vol. XXXVI. c. 523; 1818. Vol. XXXVIII. c. 573

20. Hansard's Parliamentary Debates. 3-rd Series. 1830. Vol. XXIII. c. 26-53; 1837. Vol. XXXVII. c. 147.

21. Hansard's Parliamentary Debates. 3-rd Series. 1844. Vol. LXXII. c. 1-5, 244.

22. Hansard's Parliamentary Debates. 3-rd Series. 1845. Vol. LXXVI. c. 4.

23. Levitt I. Poor Law and Pauperism // In: Atlas of Industrializing Britain 1780-1914 / Ed. by J. Langton, R. Morris. L., N. Y.: Methuens \& Co, 2003. P.160-163.

24. Malthus T. R. An Essay on the Principle of Population As It Affects the Future Improvement of Society, with Remarks on the Speculations of Mr. Godwin, M. Condorcet, and Other Writers. L.: J. Jonson, 1798. 2 Vols.

25. McCulloch J. Poor Laws // The Edinburgh Review. 1828. № 47. P. 303-330.

26. Report from Commissioners for Inquiry into the Administration and Practical Operation of the Poor Laws // P.P. 1834 Vol. XXVII. P. 63-67.

27. Report of the Poor Law Commissioners to the Secretary of State or Inquiry into the Sanitary Condition of the Laboring Population of Great Britain // P.P. 1842. Vol. XXVI. P. 3-370.

28. Report on the State of the Irish Poor in Great Britain // P.P. 1836. Vol. XXXIV. P. IX-XXV.

29. Senior N. Proposals for Extending the Irish Poor Law // The Edinburgh Review. 1846. № 84. P. $267-314$.

30. Sklyarova E. K. Crimean War and establishing of Public Health system in Great Britain // Научный альманах стран Причерноморья. 2017. № 1 (9). C. 24-29.

31. Speeches of Henry Lord Brougham upon Questions Relating to Public Rights, Duties and Interests with Historical Introductions. Philadelphia: Lea and Blanchard, 1841. 2 Vols.

32. The Builder. 1844. Vol. 2. Apr. P.187-199.

33. The Select Committee on the Poor Laws // P. P. 1819. Vol. II. P. 37-308.

34. The Quarterly Review. 1816. Vol.15. № 29. P. 187-235.

35. Townsend J. An Essay on the Poor Laws / Ed. by A. Montagu. Berkeley: University of California Press, 1971.531 p.

\section{References}

1. Aprishenko V. Y. Yniya i modenizatia: stanovlenie shotlandskoy identichnosti $v$ XVIII - pervoi polovine XIX V.V. (The Union and modernization: the formation of the Scotland ldentity). Rostov on Don: SFU publ., 2008. 288 p. (In Russian).

2. Barlova Y. E. Angliskoe zakonodatelsjvo o bednyh v XVIII - pervoi polovine XIX v. (English laws of the Poorin the XVIIIfirst half of the XIX c.) // Yaroslavski pedagogicheskii vestnik. 2010. T.1. № 3. P. 27-30. (In Russian).

3. Vasilchikov A. I. O samoupravlenii. Sravnitelny obzor ruskih i inostrannth zemskihi i obchestvennth uchrezdeny (On selfgovenment. Comparative study of Russian and foreign local and social government). St.Petersburg: E. Pratc's publishing house, 1872. Vol.1. 352 c. (In Russian).

4. Erofeev N. A. Narodnaya emigratcita I klassovaya borba v Anglii v 1825-1850 (People emigration and class struggle in England). Moscow: SA USSR publ., 1962. 536 p. (In Russian).

5. Kertman J.E. Geografiya, istoria i kultura Anglii (Geography, history and culture of England). Moscow: Vishaya skola, 1979. 384 p. (In Russian).

6. Morton A. L. listoria Anglii (The History of England). Moscow: IL, 1950. 462 p. (In Russian).

7. Polanyi K. Velikaya transfomatia: politichestie I ekonomiceskie istoki nashego vremeni (Great transformation: political and economic origins of our times). St.Petersburg: Alteya, 2002. 320 p. (In Russian).

8. Redlih I. Angliyskoe mestnoe upravlenie (English local governmemt). St.Petersburg: Altshulera publishing house, 1907. 443 p. (In Russian).

9. Sidorenko Y. A., Sklyarova E. K., Butova E. N. Formirovanie siciogigienicheskih idei v epohu urbanizacii Velicobritanii (The formation of socio hygienic ideas of Great Britain) // Humanitarnie I socialno-economicheskie nauki. 2018. No. 2 (99). P.109-114. (In Russian).

10. Sidorina T. Y. Dva veka socialnoy politici (Two years of social policy). Moscow: RSHU publ., 2005. 442 p. (In Russian).

11. An Act for the Amendment and Better Administration of the Laws Relating to the Poor in England and Wales, $1834 / / 4$ \& 5 Will. IV. c. 76. 
12. An Act for the More Effectual Relief of the Destitute Poor in Ireland, $1838 / / 1$ \& 2 Vict. c.56; An Act for the Amendment and Better Administration of the Laws Relating to the Relief of the Poor in Scotland, $1845 / /$ Vict. 8 \& 9 c. 83.

13. An Act to amend an Act made in the Present Session of Parliament, for authorizing the Issue of Exchequer Bills, and the Advance of Money for carrying on Public Works and Fisheries, and Employment of the Poor, 1817 // 57 Geo. III c. 34. P. 470-476.

14. Bentham J. Writings on the Poor Laws. Vol. I. / Ed. by M. Quinn. Oxford: OUP, 2001. 359 p

15. Brundage A. The English Poor Laws, 1700-1930. N. Y.: Palgrave, 2002. 185 p.

16. Edsall N. The Anti-Poor Law Movement 1831-1844. Manchester: Manchester University Press, 1971. 285 p.

17. Hansard's Parliamentary Debates. 1-st Series. 1807. Vol. IX. c. 541.

18. Hansard's Parliamentary Debates. 1-st Series. 1809. Vol. XIV c. 645.

19. Hansard's Parliamentary Debates. 1-st Series. 1817. Vol. XXXVI. c. 523; 1818. Vol. XXXVIII. c. 573.

20. Hansard's Parliamentary Debates. 3-rd Series. 1830. Vol. XXIII. c. 26-53; 1837. Vol. XXXVII. c. 147

21. Hansard's Parliamentary Debates. 3-rd Series. 1844. Vol. LXXII. c.1-5, 244.

22. Hansard's Parliamentary Debates. 3-rd Series. 1845. Vol. LXXVI. c. 4.

23. Levitt I. Poor Law and Pauperism // In: Atlas of Industrializing Britain 1780-1914 / Ed. by J. Langton, R. Morris. L., N.Y.: Methuens \& Co, 2003. P.160-163.

24. Malthus T. R. An Essay on the Principle of Population As It Affects the Future Improvement of Society, with Remarks on the Speculations of Mr. Godwin, M. Condorcet, and Other Writers. L.: J. Jonson, 1798. 2 Vols.

25. McCulloch J. Poor Laws // The Edinburgh Review. 1828. № 47. P. 303-330.

26. Report from Commissioners for Inquiry into the Administration and Practical Operation of the Poor Laws // P.P. 1834 Vol. XXVII. P. 63-67.

27. Report of the Poor Law Commissioners to the Secretary of State or Inquiry into the Sanitary Condition of the Laboring Population of Great Britain // P.P. 1842. Vol. XXVI. P. 3-370.

28. Report on the State of the Irish Poor in Great Britain // P.P. 1836. Vol. XXXIV. P. IX-XXV.

29. Senior N. Proposals for Extending the Irish Poor Law // The Edinburgh Review. 1846. № 84. P. 267-314.

30. Sklyarova E.K. Crimean War and establishing of Public Health system in Great Britain // Научный альманах стран Причерноморья. 2017 . № 1 (9). С. 24-29.

31. Speeches of Henry Lord Brougham upon Questions Relating to Public Rights, Duties and Interests with Historical Introductions. Philadelphia: Lea and Blanchard, 1841. 2 Vols.

32. The Builder. 1844. Vol. 2. Apr. P.187-199.

33. The Select Committee on the Poor Laws // P. P. 1819. Vol. II. P. 37-308

34. The Quarterly Review. 1816. Vol.15. № 29. P. 187-235.

35. Townsend J. An Essay on the Poor Laws / Ed. by A. Montagu. Berkeley: University of California Press, 1971. 531 p

\section{Информация об авторе}

Склярова Елена Константиновна - доцент кафедры истории Ростовского государственного медицинского университета (Ростов-на-Дону) / affina18@mail.ru

\section{Information about the author}

Sklyarova Elena - PhD in History, Associate Professor, Chair of History, Rostov State Medical University (Rostov-on-Don)/ affina18@mail.ru 